\title{
The Use of Financial Derivatives in Emerging Market Economies: An Empirical Evidence from Bosnia and Herzegovina's Non-Financial Firms
}

\author{
Emira Kozarević ${ }^{1}$, Meldina Kokorović Jukan ${ }^{1} \&$ Beriz Čivić ${ }^{1}$ \\ ${ }^{1}$ Faculty of Economics, Tuzla University, Bosnia and Herzegovina \\ Correspondence: Emira Kozarević, Faculty of Economics, Tuzla University, Bosnia and Herzegovina. Tel: \\ 387-61-178-821. E-mail: emira.kozarevic@untz.ba
}

Received: January 30, 2014

Accepted: February 19, 2014

Online Published: March 1, 2014

doi:10.5430/rwe.v5n1p39

URL: http://dx.doi.org/10.5430/rwe.v5n1p39

\begin{abstract}
This paper discusses development of financial derivatives markets in emerging market economies, focusing on the use of financial derivatives in risk management purposes of non-financial firms in Bosnia and Herzegovina. For achieving the research goals authors collected data on the derivatives market structure and types of derivative instrument traded, focusing commercial banks, because of the authors' prior knowledge of the derivatives market. Additionally, in order to assess the current state and development perspectives of derivatives usage by the non-financial firms, authors conducted a research on the random sample of non-financial firms, using data from the Foreign Trade Chamber of Bosnia and Herzegovina as well as the information from lists of derivatives users-clients provided by some banks of Bosnia and Herzegovina. The research shows that derivatives market in the country exists as an over-the-counter market, where banks play dominant role and offer different types of derivative instruments. Three types of derivatives are being offered: currency forwards, currency swaps, and interest rate forwards. The main reason for the poor offer is low demand, lack of non-financial firms' knowledge about benefits of derivatives, and low number of business operations on the global markets by the non-financial firms.
\end{abstract}

Keywords: financial derivatives, risk management, non-financial firms, emerging market economies (EME's), Bosnia and Herzegovina $(\mathrm{BiH})$

\section{Introduction}

In the last 30 years, or a bit more, trading with derivative financial instruments has become one of the most efficient means to boost the rate of return and reduce the risk in portfolio management. What is more important, as an instrument for functioning and development of the financial markets, financial derivatives provide the quality and quantity of the supply and demand of capital, improve business climate, and create opportunities for new jobs, thus contributing to the decline in unemployment.

Trading with these instruments undergoes rapid development in the last years because of the necessity for risk management in trading securities of financial as well as non-financial firms, the huge expansion of securities market, the standardization of financial instruments, and the intensive development of information and communication technologies.

The main usage of derivatives is to minimize risk for one party while offering the potential for a high return (at increased risk) to another. The wide spectrum of potential underlying assets and payoff alternatives leads to a diverse range of derivatives contracts available to be traded in the market.

\section{The Theoretical Framework}

Derivative financial instruments can be defined as securities whose values are dependent on or derived from one or more underlying assets such as bonds, equities (stocks), commodities, currencies, interest rates, indices (e.g. a stock market index, consumer price index, an index of weather conditions), etc. In the juridical sense, they represent contracts under which the parties agree to transfer underlying assets on or before determined date in the future, according to prearranged price. The value of these instruments varies as a consequence of the change of one or more market variables, for instance: securities and commodities prices, exchange rates, interest rates, indices, etc.

Financial derivatives are generally used as an instrument for risk management, more precisely to hedge financial risks, such as interest rate risk, security and commodity price risk, currency risk, interest rate risk, credit risk, etc., 
but derivatives can also be used for speculative purposes. The risk embodied in a derivative contract can be traded either by trading the contract itself (e.g. with options) or by creating a new contract which embodies risk characteristics that match, in a countervailing manner, those of the existing contract owned ( $a k a$ offsetability).

According to the way they are traded in the markets, there are generally two groups of derivatives - exchange-traded derivatives, that is financial instruments traded via specialized derivatives stock exchange or other exchanges, and over-the-counter (OTC) derivatives, which means that their terms are privately negotiated between two parties (usually, a bank and a non-financial firm).

Figure 1 shows timeline of introduction of different types of financial derivatives to the capital markets. Each derivative provides varied level of liquidity and entails certain costs and benefits. First type of "modern" derivative currency futures was introduced to the US market in 1972. Later other derivatives came in to the use, such as options and stock futures (1973), mortgage bond futures (1975), OTC currency options (1979), swaptions (1985), etc., all the way until credit derivatives (1993), single stock futures (2003), and volatility options and futures (2004).

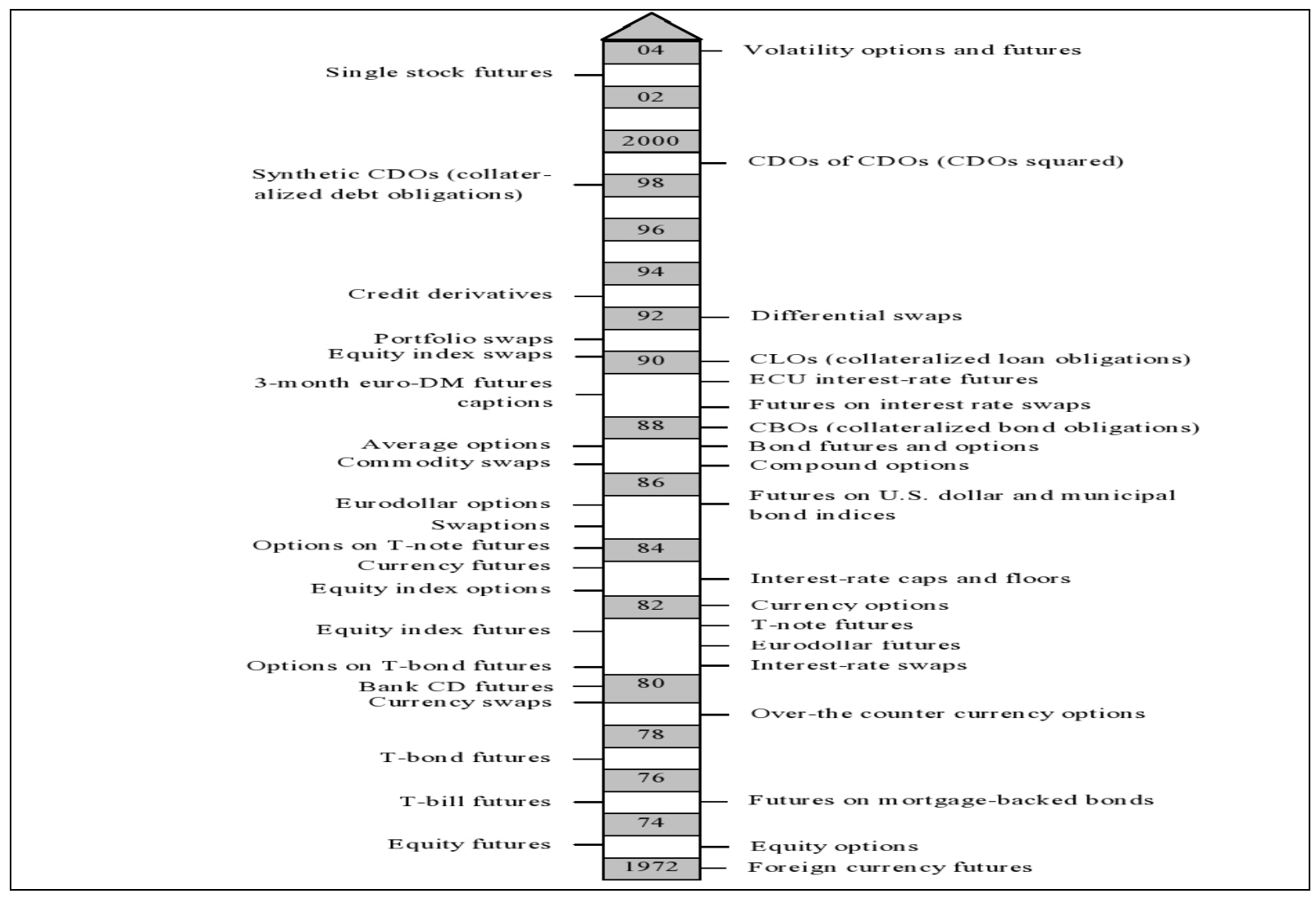

Figure 1. The evolutionary path of derivative financial instruments

Source: Crouhy, Mark, Galai (2006), p. 50

Despite the fact that the initial intention was to protect against risk, during the period of 2003 to 2007 derivatives became speculative tools often used to take on more risk in order to maximize returns. There were two intertwined issues at work here: securitized products, which were difficult to price and analyse (were traded and sold), and many positions were leveraged in order to reap the highest possible gain. Therefore, since the global financial crisis, especially after the Lehman Brothers collapse on September $15^{\text {th }}, 2008$, derivatives have been the subject of a number of disputes in a broader academic community.

\section{A Review of Previous Research}

Over the past three decades many different studies on financial derivatives use by non-financial firms were published, covering different aspects and types of derivative use in hedging a wide spectrum of risk types, which non-financial firms face while conducting their day to day business. Some most influential early studies describing the use of derivatives by non-financial firms are ones done by the following authors: Block and Gallagher (1986), Dolde (1993), 
Judge (1995), Berkman and Bradbury (1996); Bodnar and Gebhardt (1997), Hakkarainen et al., (1997), Bodnar et al. (1998), Alkebäck and Hagelin (1999), El-Masry (2001), etc.

In the mid-1980s, characterized by the growth of financial derivative market in USA, Block and Gallagher (1986) examined the corporate use of derivatives in interest rate exposure hedging activity in the USA, showing that one of five firms used interest rate futures and options to hedge the interest rate exposure, with a higher usage degree by larger firms and firms in traditionally commodity-oriented industries. Later, Dolde (1993) reported that large companies diverged greatly in the scope and sophistication of their approach to risk management, despite bigger firms could profit of a greater portfolio diversification, making the risk exposure less urgent. Hakkarainen et al. (1997) conducted a survey on interest rate risk management in the top 100 largest Finnish non-financial firms, which was the first survey of this kind conduced for European companies.

In the 1996 and following in 1998, Bodnar et al. started comprehensive studies, known as Wharton School studies, on financial derivatives use by non-financial firms in the United States (1996) and in Germany (1998). These surveys differ from the previous mentioned in wider coverage of different types of financial derivatives. While early surveys covered derivatives for hedging interest rate risk, Wharton School surveys were extended to currency and commodity derivatives.

Comparing the USA and Germany, Bodnar et. al. found that less than half of all non-financial firms in the United States use different types of derivatives, although usage is tilted heavily towards larger firms in the commodity and manufacturing sectors, while German firms are more likely to use derivatives than the US firms, with 78 per cent of German firms using derivatives compared to 57 per cent of the US firms.

Wharton School studies triggered more studies in following years, mostly in Europe. Alkebäck and Niclas (1999) provided survey evidence on the use of derivatives amongst Swedish non-financial firms. The results were directly compared with those presented in Bodnar et al. (1996). The Swedish survey revealed that lack of knowledge about derivatives within the firms was the main concern for Swedish corporations. Bodnar et al. (2003) found that Dutch firm hedge more financial risk, because of the more open economy of the Netherlands, and in that respect the firms experience far more foreign exchange exposure than the US firms. Research conducted amongst Italian firms (Bodnar et al., 2013) showed that the use of derivative instruments reflects the predominance of small businesses, industrial clusters around the northern regions, declining trade with emerging markets mostly due to the lost edge of steady lira denominations and political and economic culture of risk aversion, indicating the lack of dynamism, innovation, and financial literacy of the Italian economic situation in 2007-2008.

Above discussed researches show that non-financial firms (mostly large firms) in developed countries and countries with strong, liquid financial derivative markets frequently use these instruments for risk hedging purposes. On the other hand, the studies on the use of financial derivatives by non-financial firms inspired by the growth of financial derivatives markets in emerging market economies (EME's) disclosed different patterns of derivatives usage by the surveyed companies in these countries in comparison to developed market economies.

The research conduced in several emerging economies in Latin America - Peru (Martin, 2009) and Argentina (Tappatá et al., 2000) - and in the Balkans - Slovenia (Berk, 2006; Miloš Sprčić, 2007) and Croatia (Miloš Sprčić, 2007) - revealed different patterns of derivatives usage by the surveyed companies in these countries. For instance, in Latin America large firms do not practice a generalized use of derivatives. In this sense, there is a low percentage of participating firms and a small traded volume. Although the firms are aware of interest rate and foreign exchange risks, they do not carry out formal risk management practices. According to Martin et al. (2009), the main issue that influences the most in derivatives use is the degree of market knowledge on these financial instruments. The comparative analysis conducted to explore differences between risk management practices in Slovenian and Croatian companies has shown statistically significant evidence that Slovenian companies use all types of derivatives, especially structured derivatives, more intensively than Croatian companies. These findings are consistent with the research prediction that Slovenian companies have more advanced risk management practices than Croatian companies.

Besides that, Pramborg (2005) compared the hedging practices of Swedish and Korean non-financial firms. Findings of this survey suggested that the aim of hedging differed between firms in the two countries. Korean firms mostly focused on reducing fluctuations in cash flows, while Swedish firms more commonly emphasized reducing fluctuations of accounting numbers. The proportion of firms that used derivatives was significantly lower in the Korean than in the Swedish sample, a finding that may steam from the relative immaturity of the Korean derivatives market. The evidence showed that Korean firms hedged as much as Swedish firms, but substituted foreign debt for derivatives. Furthermore, Korean firms appeared to be less rigorous than Swedish firms in overseeing risk 
management activity. Finally, a large proportion of firms in both countries used a profit-based approach to evaluating the risk management function.

Anand and Kaushik (2007) analysed the derivatives usage in India, focusing on foreign exchange risk management. The survey revealed that the most of the respondent firms have documented foreign exchange risk management plan (policy, programme). The firms with high debt ratio are more likely to use foreign currency derivatives.

Comprehensive international study conducted by Bartram, Brown, and Fehle (2009) involving 50 countries worldwide examined what motivates the use of financial derivatives by corporations. One of the conclusions was that firms with less liquid derivatives markets, typically in middle-income countries, are less likely to hedge. This finding is consistent with the assertions of some policy makers that derivatives could be important in limiting the severity of economic downturns in developing economies. The impact of this finding is reinforced by other results showing that these firms, which are typically located in countries with higher economic and financial risk, prefer to hedge more often, ceteris paribus. Consequently, it is likely that financial policy makers could facilitate corporations' financial risk management activities by pursuing strategies that encourage the development of local currency derivatives markets.

\section{An Overview of Financial Derivatives Markets in EME's, with a Focus on BiH}

\subsection{The Derivatives Markets Development in EME's: Size, Structure, and Impact on the Economic Growth}

According to the recent data, the size and the scope of derivative instruments being traded in EME's, both exchange and over-the-counter markets is continuously expanding. (Note 1) Still, in comparison to advanced economies, it is rather small. According to the statistical data, derivative instruments are equally traded on derivative exchanges and OTC markets, as it is illustrated in figure 2. The figure also shows that derivatives turnover increased for 5 times since 1998 in EME's.

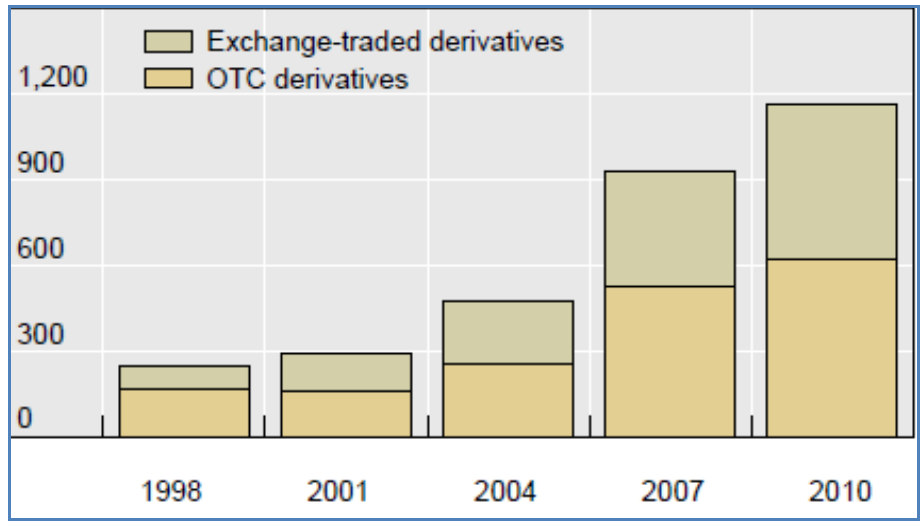

Figure 2. Global derivatives turnover in EME's

Source: Mihaljek, Packer (2010), p. 45

One of the basic characteristic of derivatives markets in EME's is trading of different types of financial derivatives at OTC markets. (Note 2) According to the first comprehensive study of derivatives markets development published in 2010, (Note 3) the most traded derivative products in EME's are foreign exchange derivatives (such as outright forwards, foreign exchange swaps, currency swaps, options, and other foreign exchange derivatives) as well as interest rate derivatives.

This study shows that derivatives markets in EME's remain small compared to those in advanced economies. Average daily turnover of derivatives in 33 EME's for which data are available was $\$ 1.2$ trillion in April 2010 (i.e. 6.2 per cent of those economies' GDP), compared to $\$ 13.8$ trillion (i.e. 36 per cent of GDP) in advanced economies. Though small, derivatives markets in EME's have expanded rapidly - average daily turnover has increased by 300 per cent since 2001 and by 25 per cent over the past three years, despite the global financial crisis.

During the period of 2010 to 2012 we conducted the first extensive study on financial derivatives market development in $\mathrm{BiH}$. Two main goals of the study were set. First, to obtain information on derivatives market structure and types of derivative instruments traded. In this part of the research we focused on commercial banks since derivatives market in $\mathrm{BiH}$ operates only as OTC market. (Note 4) Second goal was to assess the state and perspectives of derivatives usage by non-financial firms. 


\subsection{The Current State of the Derivatives Market in BiH}

In order to assess overall level of derivative instruments demand in $\mathrm{BiH}$, types of derivatives offered by banking sector and possibilities and limitations of introducing derivatives market as a segment in the BiH stock exchanges (Sarajevo and Banja Luka Stock Exchange) a research was conducted amongst commercial banks operating in BiH. For this purpose a specific questionnaire was designed and sent to all BiH banks. (Note 5) The sample included all 29 (commercial) banks, 19 in the Federation of $\mathrm{BiH}(\mathrm{F} \mathrm{BiH})$ and 10 in Republika Srpska (RS), according to the data from banking agencies in $\mathrm{F} \mathrm{BiH}$ and $\mathrm{RS}$.

Based on the answers provided by the banks it was concluded that, besides low supply of derivatives in banking sector (34.48 per cent), OTC derivatives market in $\mathrm{BiH}$ is relatively "young" and exists only for the last eight years. There is no formally organized derivatives market as a derivatives exchange. Also, demand for derivatives in $\mathrm{BiH}$ is extremely low. Data show that a bank, who is the biggest supplier of derivatives, closed only 10 contracts for derivatives with average value of 750,000.00 BAM (approx. 383,500.00 euros) from August 2008. Other banks, all together, closed only 4 contracts for derivatives. (Note 6) Hence, the research results indicate that derivatives market in $\mathrm{BiH}$ is in the early phase of development, which is an indicator of low derivatives market potential in $\mathrm{BiH}$.

Commercial banks offer just three types of derivatives, which are commonly used for foreign exchange risk and credit risk hedging - currency forwards, currency swaps, and interest rate swaps. The research shows that all three types of derivatives are offered by 12.5 per cent surveyed banks, currency forward and currency swaps are offered by 50 per cent of surveyed banks, and 37.5 per cent surveyed banks are only offering currency forwards. In other words, financial derivatives market in $\mathrm{BiH}$ has the same characteristics as all other markets in EME's, with a few types of financial derivatives traded in OTC markets.

Demand for derivative instruments is also very low. According to the survey, the biggest interest amongst the bank clients is for currency forwards, with average grade 2.33, then for currency swaps (2.20), and after that interest rate swaps (2.00). (Note 7) Moreover, information provided by the users of derivatives, through an informal communication, revealed that major reasons for low usage of derivative instruments is due to lack of information about procedure of derivatives usage and lack of knowledge about potential benefits of these instruments in domain of risk management. Also, the major limiting factor of larger derivatives use can be the relatively low number of business operations of $\mathrm{BiH}$ firms on foreign markets.

Non-financial firms have major role in the structure of users who closed contracts for derivatives with the surveyed banks. According to the survey dominant users of derivatives (in 78.6 per cent of all cases) are non-financial firms involved in production and distribution of oil and oil derivatives, furniture production companies, trading companies (especially trading companies that import from China), gas trading and supplying companies, and IT companies. Other users of contracts for derivatives are the banks themselves, but in less lower percentage (21.4 per cent).

Additionally, the survey reveals that most important conditions and/or limitations for derivatives purchase by non-financial firms are as following:

- Necessity of having deposit on a special bank account for covering forward transaction (usually 10 per cent of the transaction value),

- Value of the client turnover with the bank,

- Considerable need for buying different currencies, and

- Collateral (depending on the clients' credit worthiness).

A positive fact is that surveyed banks are giving great attention to offer of basic financial instruments, and, therefore, have organized special departments (trading and asset departments) in their organization structures with specialized personnel for this type of offers. A negative side related to operations on the OTC derivatives market is that only 25 per cent of the surveyed banks hired specialized individuals with adequate knowledge and international certificates for trading with financial instruments (e.g. ACI Dealing Certificate), while other banks are only satisfying legal obligations and hiring personnel with adequate brokerage certificates and investment advisors certificates issued by the Securities Commissions in $\mathrm{F} \mathrm{BiH}$ and $\mathrm{RS}$.

\subsection{The Financial Derivatives Usage by the Non-Financial Firms in BiH}

To evaluate current state of the use of financial derivatives by BiH non-financial firms, a field research was conducted during 2011 and 2012 on the survey sample of 76 firms classified as real and/or possible users of derivatives. Data was collected by using a questionnaire (i.e. the technique of written structured investigation) consisting of 26 questions. The questionnaire was disseminated by e-mail and the rate of response was 36.84 per cent. (Note 8 ) 
The research discloses that 25 per cent of surveyed firms who responded to the questionnaire are still using financial derivatives. More than half of the firms using financial derivative for risk hedging purposes ( 57.14 per cent) have less than 50 employees. Detailed structure of the surveyed firms by the number of employees is given in Figure 3.

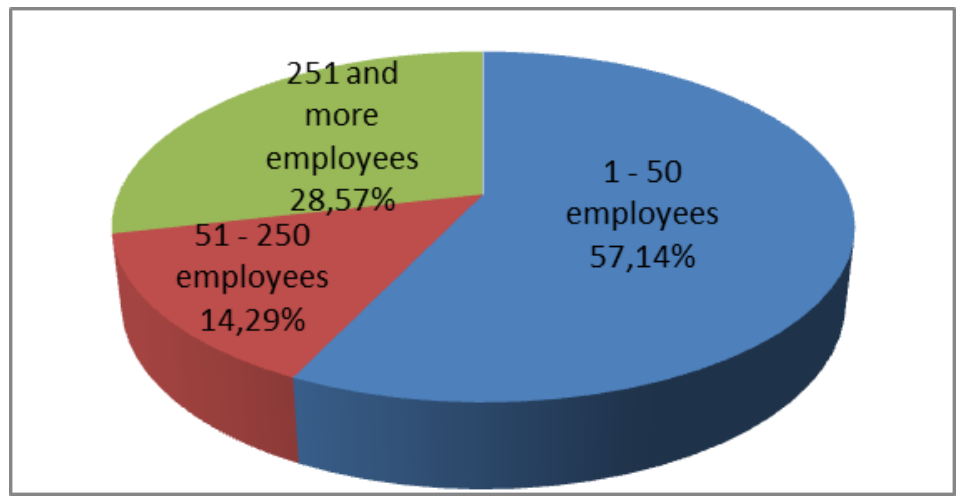

Figure 3. Structure of the surveyed firms (financial derivatives users in $\mathrm{BiH}$ ) by the number of employees

Regardless of the fact that most of the surveyed firms can be categorized as small or mid-sized, they have relatively high revenues. As it can be observed from Figure 3, 42.86 per cent of the surveyed firms have revenues of more than 30 million BAM (approx. 15.34 million euros).

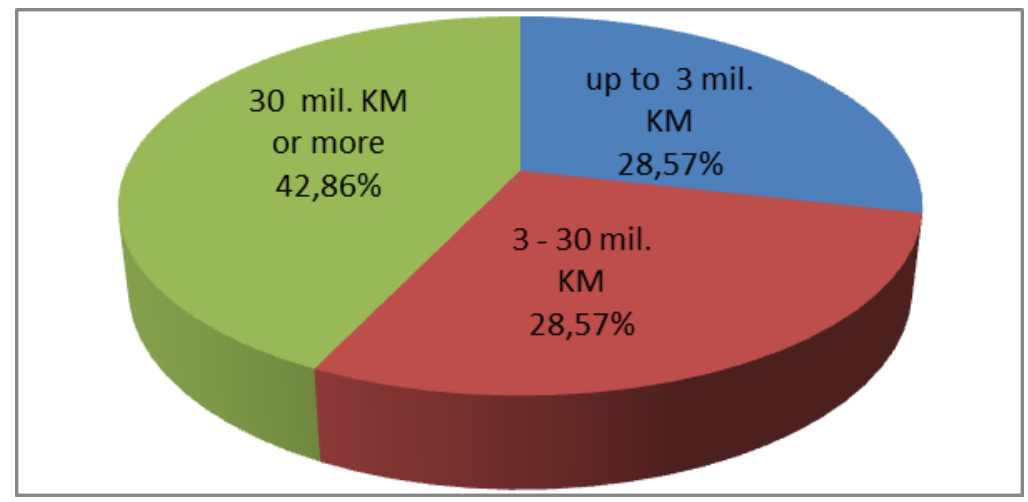

Figure 4. Structure of the surveyed firms (financial derivatives users in $\mathrm{BiH}$ ) by revenues

Considering the type of business, most of the surveyed firms, financial derivatives users (57.14 per cent), are trading firms (predominately importers). Further, 28.57 per cent of the derivatives users are production firms, while only 14.29 per cent are service companies (Figure 5).

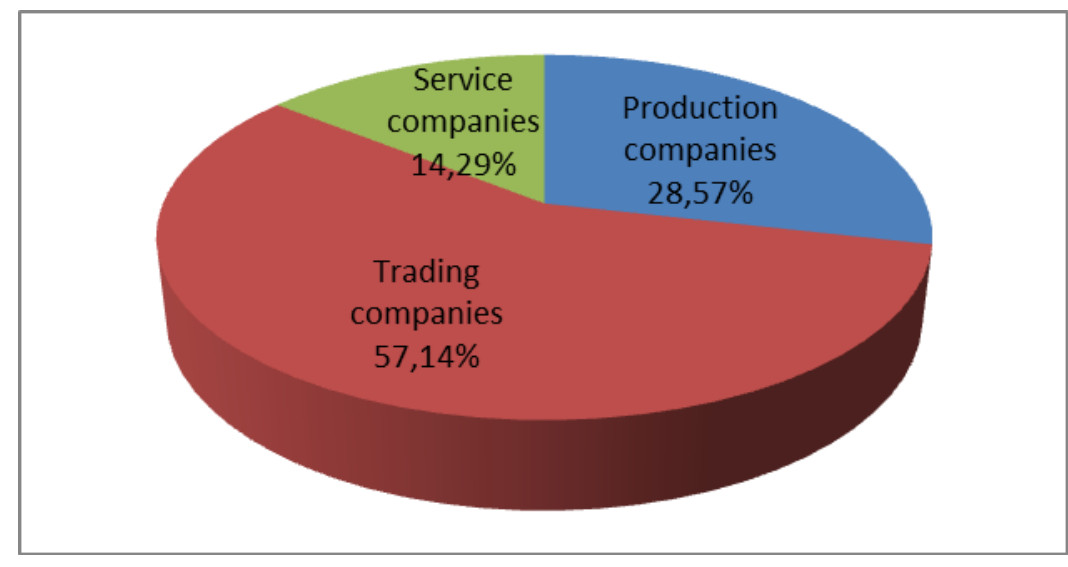

Figure 5. Structure of the surveyed firms (financial derivatives users in $\mathrm{BiH}$ ) by the sector 
The research indicates that surveyed firms use all types of financial derivatives available in the OTC derivatives markets. More precisely, 66.67 per cent of the firms use interest rate swaps and currency forwards, 50 per cent currency options and currency swaps, while 16.67 per cent use structured derivatives.

The level of importance of particular financial derivatives for risk management differs. Figure 6 illustrates the structure of importance of varied types of OTC financial derivatives assessed by the surveyed firms. As assessed by the one third of the surveyed firms, currency options, currency forwards, and interest rate swaps have the highest importance for financial risk management purposes. At the same time, these instruments are assessed as the least important by 16.67 per cent of the surveyed firms.

Structured derivatives, interest rate derivatives, and currency forwards are reported as moderate important by 16.67 per cent of the firms derivatives users, while currency swaps are reported as moderate important by the 50 per cent of the firms.

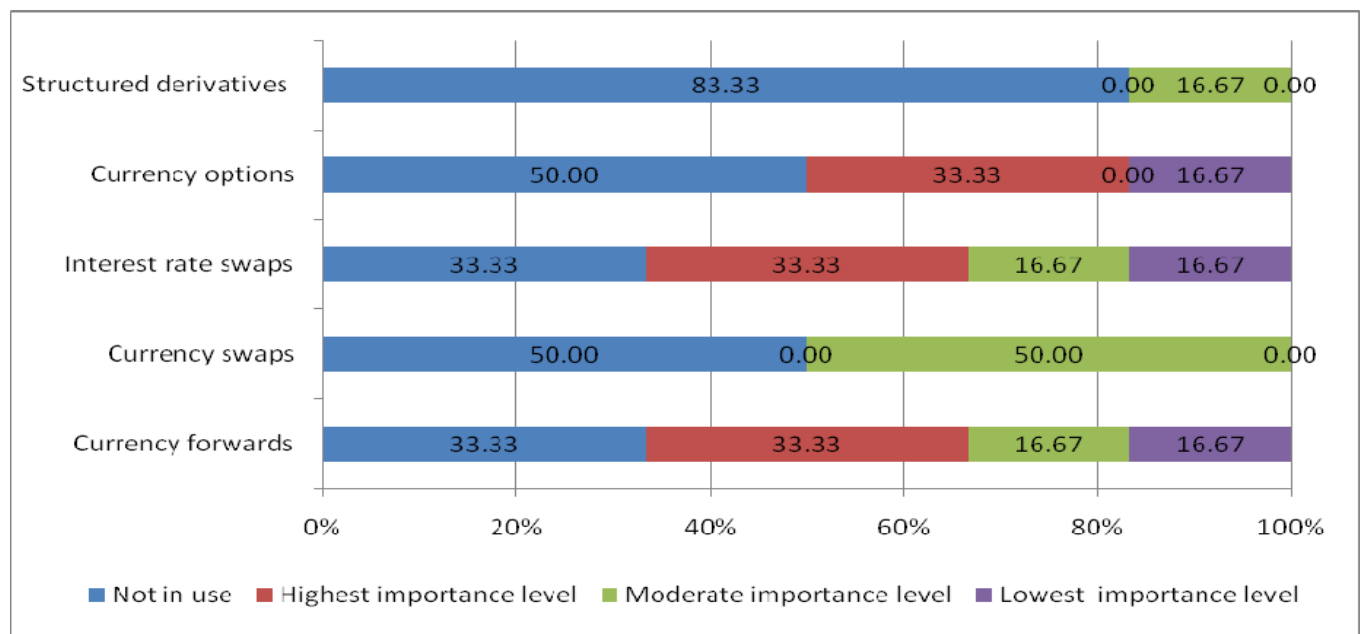

Figure 6. The structure of importance of varied types of OTC financial derivatives assessed by the surveyed firms

\section{Development Perspectives of the Financial Derivatives Market in BiH}

Future development of financial derivatives market in $\mathrm{BiH}$ will greatly depend on non-financial firms understanding of derivatives importance and benefits in managing business risks since the firms are major users of OTC derivatives. What is more, development of derivatives market is closely connected to general knowledge on financial derivatives usage.

In order to assess perspectives of financial derivatives usage by $\mathrm{BiH}$ companies, we evaluated the level of knowledge on financial derivatives amongst the surveyed firms. More than three quarters of the firms ( 75.60 per cent) employs faculty educated employers with a degree in economics, which represent a solid base for development of business activities related to managing both financial and non-financial risks.

Furthermore, just over half of the surveyed companies (57.14 per cent) have established risk management sector within their organization structure. Even though financial risk management activities can be allocated to different sectors within organization structure, evidences of successful businesses indicates that risk management should be carried out within organized risk management unit.

Taking into consideration business dynamics of the firms, need for education is constant. Therefore, it is important to strengthen the firm's position in competitive market by further education of employees. In that respect, an encouraging fact is that management of 85.71 per cent of the surveyed firms think that their employees need additional education in financial derivatives usage.

Another encouraging fact is that management of 85.71 per cent of the surveyed firms understands the importance of financial derivatives usage in risk management. This data is more important when linked to the information on positive experiences of current derivatives users since most of them did not have negative experiences regarding a default of counterparty. (Note 9)

When asked if they expect to use financial derivatives in their future business operations most of the surveyed firms ( 85.71 per cent) replied positively. Remaining 14.29 per cent of the firms believe that financial derivatives will not be used in their future business operations. 
Figure 7 shows types of financial derivatives which are going to be used in future by the surveyed firms. Almost 60 per cent of the surveyed firms are going to use financial derivatives for hedging interest rate risk (interest rate swaps and interest rate options). Almost 43 per cent of the surveyed firms are going to use financial derivatives for hedging currency risk: currency forwards and currency swaps, while less than 15 per cent are going to use currency options. None of the companies reported intention to use financial derivatives for commodity price risk or stock price risk hedging.

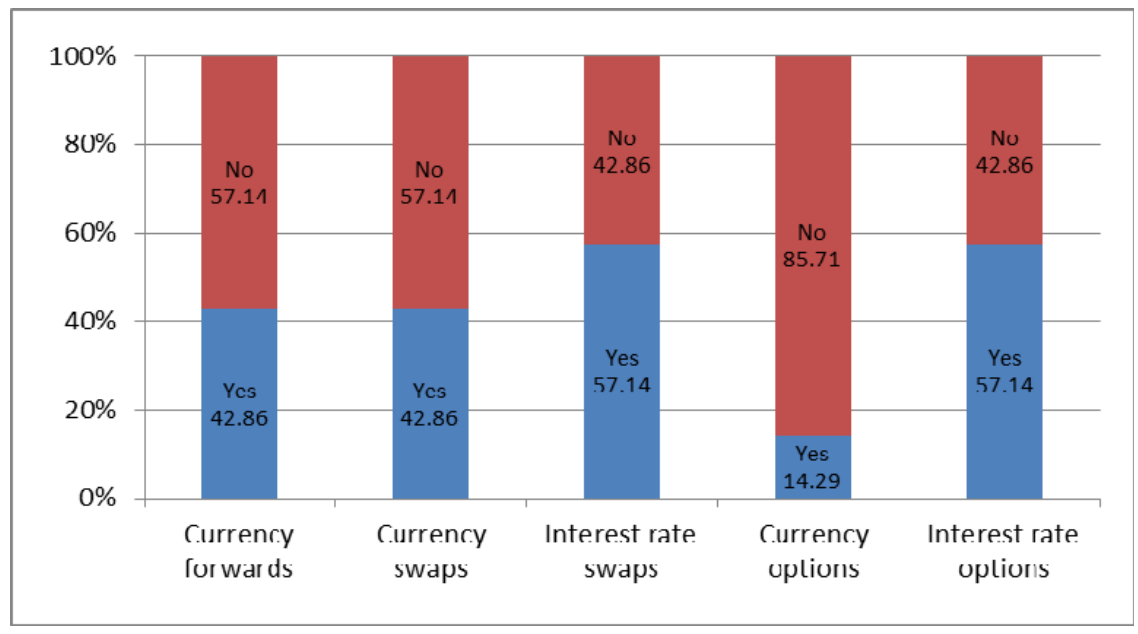

Figure 7. The structure of intended use of financial derivatives by the surveyed firms

The firms which reported that are not using (and are not going to use) financial derivatives for risk hedging indicated following reasons to explain the limited practice in the derivatives market:

-Costs of risk management are greater than benefits;

-Financial reporting requirements for risk management activities;

-Lack of knowledge on financial derivatives by the firm's management;

-Difficulties in monitoring/measuring contract effectiveness;

-Risk exposures are managed more efficiently by other means;

-Exposures to currency, interest rate, or commodity price risk are not significant.

Figure 8 illustrates the most important factors for not using derivatives by the fraction of the surveyed firms reported that they are not using derivative financial instruments.

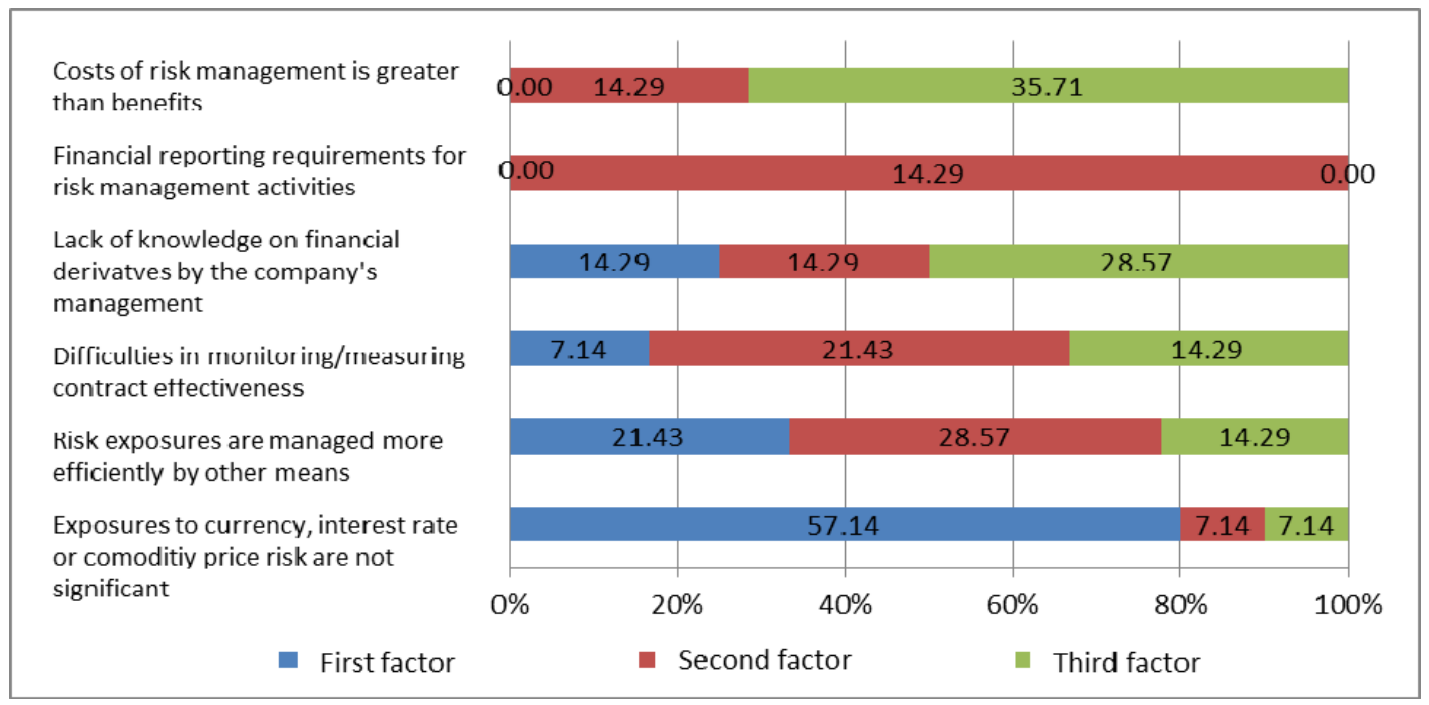

Figure 8. The most important factors for not using derivatives 
As Figure 8 indicates, more than half of the surveyed firms (57.14 per cent) indicated that the first factor explaining limited use of financial derivatives is that exposures to currency, interest rate, or commodity price risk are not so relevant. Moreover, less than quarter of the firms indicated following reasons as the first factor for limited use of financial derivatives in risk hedging practices - risk exposures are managed more efficiently by other means (reported by 21.43 per cent of the firms), lack of knowledge on financial derivatives by the firm's management (reported by 14.29 per cent of the firms), and difficulties in monitoring/measuring contract effectiveness (reported by only 7.14 per cent of the firms).

\section{Concluding Remarks}

Derivative financial instruments are an important tool for the development of capital markets and broader economy. Financial and non-financial firms utilize derivatives as a key tool to protect against risks that are inherent to their businesses. Recently the trading volume of derivatives in advanced economies has escalated rapidly, and non-financial firms continue to purchase and trade them in ever-greater numbers. As far as EME's are concerned, the derivatives markets, functioning mainly as OTC markets, remain small compared to those in advanced economies but show significant growth.

Analogously, the derivatives market in $\mathrm{BiH}$ exists as an OTC market, where banks play dominant role and offer different types of derivative instruments. Three types of derivatives are being offered: currency forwards, currency swaps, and interest rate forwards. The main reason for a poor offer by the banks is low demand, lack of the non-financial firms' knowledge about benefits of derivatives (but lack of the knowledge of $\mathrm{BiH}$ banks personnel as well), and the relatively low number of business operations on the global market by $\mathrm{BiH}$ non-financial firms.

Main conclusion of the research is that in the near future there would be no need for establishing organized derivatives market, as a segment of the stock exchanges in $\mathrm{BiH}$ (SASE and BLSE), what would be a key limitation for the further financial market development in general. Much more likely that at one point of time in the future comes to the formation of a regional derivatives exchange if not Western Balkans countries then the South East Europe countries.

In the end, it is also not irrelevant, the surveyed firms emphasized that undoubtedly there is a need for further both basic education and advanced trainings in the field of business operations with derivatives.

\section{References}

Alkeback, P., \& Hagelin, N. (1999). Derivatives usage by non-financial firms in Sweden with an international comparison. Journal of International Financial Management and Accounting, 10(2), 105-120.

Bartram, S. M., Brown, G. W., \& Fehle, F. R. (2009). International Evidence on Financial Derivatives Usage. Financial Management, 38(1), 185-206. http://dx.doi.org/10.1111/j.1755-053X.2009.01033.x.

Berk, A. (2006). The Use of Derivatives in Slovenian Non-Financial Firms: Is Financial Risk Already Well Managed? Proceedings of Rijeka Faculty of Economics: Journal of Economics and Business, 24(2), 225-256. Retrieved from http:/hrcak.srce.hr/index.php?show=toc\&id_broj=692\&lang=en

Berkman, H., \& Bradbury, M. E. (1996). Empirical evidence on corporate use of derivatives. Financial Management, 25(2), 5-13.

Block, S. B., \& Gallagher, T. J. (1986). An empirical study of the utilization of futures and options by corporate management. Financial Review, 21(3), 73-78.

Bodnar, G. M., \& Gebhardt, G. (1999). Derivatives usage in risk management by U.S. and German non-financial firms: a comparative survey. Journal of International Financial Management and Accounting, 10, 153-187.

Bodnar, G. M., Consolandi, C., Gabbi, G., \& Jaiswal-Dale, A. (2013). Risk Management for Italian Non-Financial Firms: Currency and Interest Rate Exposure. European Financial Management, 19(5), 887-910. http://dx.doi.org/10.1111/j.1468-036X.2012.00659.x

Bodnar, G. M., De Jong, A., \& Macrae, V. (2003). The Impact of Institutional Differences on Derivatives Usage: a Comparative Study of US and Dutch Firms. European Financial Management, 9(3), 271-297. http://dx.doi.org/10.1111/1468-036X.00221.

Bodnar, G. M., Hayt, G. S., \& Marston, R. C. (1998). 1998 Wharton survey of financial risk management by U.S. non-financial firms. Financial Management, 27(4), 70-91.

Crouhy, M., Galai, D., \& Mark, R. (2006). The essentials of risk management. McGraw-Hill, New York.

Dolde, W. (1993). The trajectory of corporate financial risk management. Journal of Applied Corporate Finance, 6(3), $33-41$. 
Hakkarainen, A., Kasanen, E., \& Puttonen, V. (1997). Interest rate risk management in major Finnish firms. European Financial Management, 3(3), 255-268.

Kozarević, E., \& Kokorović Jukan, M. (2011). Derivatives market development in Bosnia and Herzegovina: present or (far) future? International Journal of Management Cases (IJMC), Special Issue CIRCLE Conference University of Dubrovnik, Croatia, 13(3), 637-646.

Martin, M. A., Rojas, W., Erausquin, J. L., Yupanqui y Edgar Vera, D., \& Bauer, W. (2009). Derivative Usage by Non-Financial Firms in Emerging Markets: The Peruvian Case. Journal of Economics, Finance and Administrative $\quad$ Science, $\quad$ 14(28), 73-86, $\quad$ Retrieved from http://papers.ssrn.com/sol3/papers.cfm?abstract_id=1549864

Mihaljek, D., \& Packer, F. (2010, December). Derivatives in emerging markets. BIS Quarterly Review, 43-58.

Miloš Sprčić, D. (2007). The Derivatives as Financial Risk Management Instruments: The Case of Croatian and Slovenian Non-financial Companies. Financial Theory and Practice, 31(4), 395-420.

Pramborg, B. (2005). Foreign exchange risk management by Swedish and Korean nonfinancial firms: a comparative survey. Pacific-Basin Finance Journal, 13, 343-366.

Tappatá, M. E., Levy Yevaty, E., \& Jakoniuk, G. (2000). El Uso de Instrumentos Derivados en Empresas no Financieras: El caso de Argentina. Working Paper, Universidad Torcuato di Tella.

\section{Websites}

http://komorabih.ba/

http://www.abrs.ba

http://www.bis.org/publ/rpfx13.htm

http://www.blberza.com

http://www.fba.ba

http://www.sase.ba

\section{Notes}

Note 1. According to the Bank for International Settlement (BIS) Triennial Central Bank Survey, which is the most comprehensive source of information on the size and structure of global foreign exchange and OTC derivatives markets (the survey data is available at http://www.bis.org/publ/rpfx13.htm).

Note 2 . In contrast to emerging markets, financial derivatives in advanced economies are commonly exchange traded products.

Note 3. For further information see: Mihaljek, D. \& Packer, F. (2010) "Derivatives in emerging markets", BIS Quarterly Review (December), p. 43-58.

Note 4. See: Kozarević, E. \& Kokorović Jukan, M. (2011) "Derivatives market development in Bosnia and Herzegovina: present or (far) future?", International Journal of Management Cases (IJMC), Special Issue CIRCLE Conference University of Dubrovnik, Croatia, Vol 13, Issue 3, p. 637-646.

Note 5. Questionnaire included 13 questions, divided in few sections. The survey was conducted according to ICC/ESOMAR International Code on Market and Social Research.

Note 6 . This data should be considered with caution because not all the surveyed banks answered the question.

Note 7. The surveyed banks were asked to assess demand for derivative instruments through the grading system, where 1 means "there is no demand", 2 "low demand", 3 "moderate demand", 4 "high demand", and 5 "very high demand".

Note 8. Actually, at first, a sample of 30 companies was created using a generator of pseudo-random numbers and the Foreign Trade Chamber of $\mathrm{BiH}$ database of 600 exporting/importing companies. Unfortunately, the rate of responses to the questionnaire was only 10 per cent. After that, it was decided to form another sort of random sample using data from the Foreign Trade Chamber of $\mathrm{BiH}$ as well as the information from lists of derivatives users-clients provided by some $\mathrm{BiH}$ banks.

Note 9. Research shows that financial derivatives users in large extent (85.71 per cent) have positive experiences in transactions with financial derivatives in terms of the counterparty risk. 